\title{
New Occurrence of Atlantic Tripletail, Lobotes surinamensis (Bloch, 1790) from the Turkish Part of the Aegean Sea, with Biological Notes
}

\author{
İsmail Burak DABAN ${ }^{* 1}$, Koray CABBAR ${ }^{1} \mathbb{D}$ \\ ${ }^{1}$ Marine Science and Technology Faculty, Çanakkale Onsekiz Mart University, 17100, Çanakkale, Turkey \\ "Corresponding Author: burakdaban@gmail.com
}

Received 22 October 2020; Accepted 02 January 2021; Release date 01 September 2021.

How to Cite: Daban, İ. B., \& Cabbar, K. (2021). New Occurrence of Atlantic Tripletail, Lobotes surinamensis (Bloch, 1790) from the Turkish part of the Aegean Sea, with biological notes. Acta Aquatica Turcica, 17(3), $327-333$. $\underline{\text { https://doi.org/10.22392/actaquatr.814774 }}$

\begin{abstract}
A new record of Lobotes surinamensis (Bloch, 1790) around Saros Bay, North Aegean Sea is presented, based on a single hermaphrodite specimen with detailed biological information. On 12 June 2018, the specimen was captured by fishermen with gillnets at a depth of $25 \mathrm{~m}$. Sex, age, and stomach content were determined. This new record proves the Northernmost distribution of the species in the Turkish part of the Aegean Sea.
\end{abstract}

Keywords: Non-native, spread, record, population, Aegean Sea

Ege Denizi'nin Türkiye Kıyılarından Atlantik Üç Kuyruk Lobotes surinamensis (Bloch, 1790) Yeni Kaydı ve Bazı Biyolojik Özellikleri

\section{Özet}

Bu çalışmada, Lobotes surinamensis (Bloch, 1790)'in Saroz Körfezi'ndeki yeni kaydı tek dişi birey ile detaylı biyolojik bilgileriyle birlikte verilmiştir. Birey balıkçıların uzatma ağlarından 25 m derinlikte 12 Haziran 2018 tarihinde yakalanmışt ır. Cinsiyet, yaş ve mide içeriği belirlenmiştir. Bu yeni kayıt türün Kuzey Ege'nin Türk sularındaki en kuzey dağılımını göstermektedir.

Anahtar Kelimeler: Yerel olmayan, yayılım, kayıt, popülasyon, Ege Denizi

\section{INTRODUCTION}

Atlantic tripletail, Lobotes surinamensis (Bloch, 1790) is a member of the family Lobotidae, is represented only single species in Turkey. Tropical and temperate waters of all oceans host Atlantic tripletail. A widespread distribution of this species only restricted around Eastern Pacific (Froese and Pauly, 2018). Although it is considered rare around the Mediterranean (Tortonese, 1975), Atlantic Tripletail continues its distribution towards the North day by day.

According to documented records, the Atlantic Triple Tail has spread from the Arabian sea and the Oman sea to the entire Mediterranean basin (Manilo and Bogorodsky, 2003; Al-Jufaili et al., 2010; Javad et al., 2015). After being identified in Sicilian waters (Doderlein, 1875), it has been reported in the Southeastern Mediterranean (Tortonese, 1975) and Israeli waters (Golani, 1996). When the records of the last 20 years were examined, many records in the Mediterranean Basin showed that the species has become more common in this region (Camilleri et al., 2005; Minos and Economidis, 2007; Zava et al., 2007; Deidun et al., 2010; Dulcic et al., 2014a; Dulcic et al., 2014b). On a large scale, Northernmost occurrance of this species were notified from Nova Scotia (Gilhen and McAllister, 1985) in the North Atlantic; from the Russian waters (Kharin et al., 2009) in the Western Pacific; Barcelona (Palom, 1991) in the Western Mediterranean and Rasa Bay (Dulcic et al., 2014b) in the Adriatic. Northern extension of Atlantic Tripletail in the Aegean Sea has been recorded by Greek and Turkish researchers. In the Aegean Sea, the first record was given by Economidis (1973). In the Turkish part, Akyol and Kara (2012) were realized first record from Izmir Bay. Up to today, the Northernmost occurrence has been identified by Tunçer and Önal (2016) from Çanakkale Strait. Also, 
Gönülal and Güreşen (2014) were reported from Gökçeada Island and Bilge et al. (2017) were reported from Southern Aegean Sea.

Detailed studies were conducted on age, growth, reproductive biology, and feeding habits of the species around the Gulf of Mexico (Brown-Peterson and Franks, 2001; Franks et al., 2003; Strelcheck et al., 2004). Due to limited occurrences, no study has been found in the Mediterranean yet.

The present study aims to report the Northernmost occurrence of the L. surinamensis, in the Turkish part of the Aegean Sea. Beside, some biological notes were shared to increase knowledge on the biology of this species.

\section{MATERIALS and METHODS}

One hermaphrodite individual was provided by a local fisherman on 12 June 2018 from Sultaniçe shores in the Saros Bay, North Aegean Sea. A single specimen of Atlantic Tripletail was caught with gillnets at a depth of $25 \mathrm{~m}$. The specimen was identified according to Tortonese (1975) and Dulcic et al. (2014a). It was photographed, some morphometric characters measured and meristic characters were counted (Figure 1).

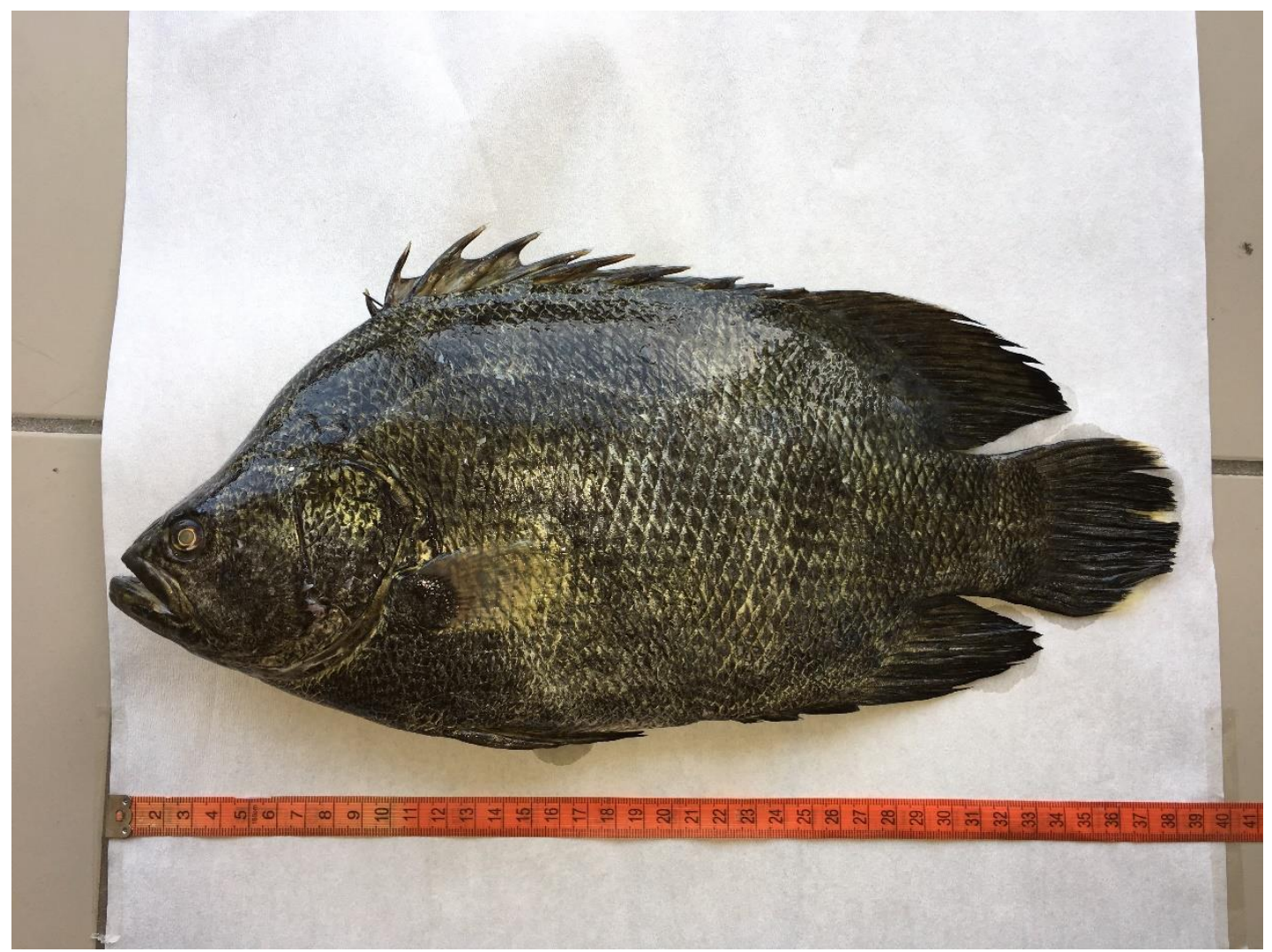

Figure 1. Atlantic Tripletail, Lobotes surinamensis

The total length (TL) was measured to the nearest millimeter using a measuring board, and the total weight, gonad weight, and otolith weight were recorded to the nearest gram using precision scales. The length and width of otoliths were measured using the Q-Image digital imaging program. Sex and maturity stages were determined by macroscopic observation of male and female gonads. Age was estimated by interpreting annual growth rings on otolith according to Iglesias and Dery's (1981) method. Readings were made by three independent researchers. Otolith rings were counted under reflected light by placing the concave side of the otolith against the glass surface. The sexual maturity stage was determined with Holden and Raitt's (1974). The stomach was dried on a blotting paper, weighted with precision scales, and prey were sorted and identified to the lowest possible taxonomic level. 


\section{RESULTS}

Some morphometric measurements and meristic counts of the individual are given in Table 1. The total length and weight were measured as $379 \mathrm{~mm}$ and $1254.6 \mathrm{~g}$, respectively. The lateral line goes along nearly straight and has 56 ctenoid scales. The species has a relatively long head with a $29 \%$ of the total length. Anus is situated about $75 \%$ of the total length through the backward. Body morphology can be definable as highly compressed with a high body depth, corresponding to $48 \%$ of the total length.

Table 1. Morphometric measurements, otolith measurements, and meristic counts of the single specimen of $L$. surinamensis (Bloch, 1790) and comparison with previous data obtained from varied studies.

\begin{tabular}{|c|c|c|c|c|c|c|}
\hline \multirow{3}{*}{$\begin{array}{l}\text { Region } \\
\text { Sex }\end{array}$} & \multirow{3}{*}{\begin{tabular}{|c|} 
In this study \\
$\begin{array}{c}\text { North Aegean } \\
\text { Sea }\end{array}$ \\
Hermaphrodite
\end{tabular}} & \multicolumn{2}{|c|}{ Amor et al. (2016) } & \multirow{3}{*}{$\begin{array}{c}\begin{array}{c}\text { Kechaou } \\
\text { et al. } \\
(2018)\end{array} \\
\text { Tunisian } \\
\text { Waters }\end{array}$} & \multirow{3}{*}{$\begin{array}{c}\begin{array}{c}\text { De Carlo et al. } \\
(2017)\end{array} \\
\text { Ligurain Sea } \\
\text { Hermaphrodite }\end{array}$} & \multirow{3}{*}{$\begin{array}{c}\begin{array}{c}\text { Javad et al } \\
(2015)\end{array} \\
\text { Oman Sea } \\
-\end{array}$} \\
\hline & & \multicolumn{2}{|c|}{$\begin{array}{c}\text { North-Eastern } \\
\text { Tunisia }\end{array}$} & & & \\
\hline & & q & q & & & \\
\hline \multicolumn{7}{|c|}{ Morphometric measurements (cm) } \\
\hline Total length (TL) & 37.9 & 39 & 25 & 43 & 42.7 & 63.0 \\
\hline Standard length (SL) & 33.5 & 33.4 & 19.9 & 36.5 & - & 53.0 \\
\hline Head length & 11 & 5.5 & 5.1 & 12 & 12.4 & 24,5 \\
\hline Interorbital space & 3.5 & 2.0 & 1.7 & 3.5 & 3.4 & - \\
\hline Predorsal length & 12.5 & 6.7 & 5.1 & 13 & 12.9 & 17.0 \\
\hline Preanal length & 21.5 & 22.5 & 15.8 & 24 & 27 & 36.5 \\
\hline Prepectoral length & 11 & - & - & - & 13.3 & 19.0 \\
\hline Prepelvic length & 12.5 & 5.7 & 4.7 & 12.5 & 15.6 & - \\
\hline Max.Body depth & 18 & - & - & - & 15.5 & 34.0 \\
\hline Eye diameter & 1.3 & - & - & - & 1.2 & 2.0 \\
\hline Preorbital length & 2.5 & - & - & - & 2.4 & - \\
\hline \multicolumn{7}{|l|}{ Meristic counts } \\
\hline Dorsal fin rays & $\mathrm{XII}+16$ & $\mathrm{XII}+16$ & $\begin{array}{c}\mathrm{XII}+ \\
15\end{array}$ & $\mathrm{XII}+16$ & $\mathrm{XII}+15$ & - \\
\hline Anal fin rays & $\mathrm{III}+12$ & $\mathrm{III}+13$ & $\begin{array}{c}\mathrm{III}+ \\
12\end{array}$ & $\mathrm{III}+12$ & $\mathrm{III}+11$ & - \\
\hline Pectoral fin rays & 16 & 12 & 12 & 13 & 15 & - \\
\hline Caudal fin rays & 16 & 18 & 18 & 18 & 16 & - \\
\hline Pelvic fin rays & $\mathrm{I}+5$ & $\mathrm{I}+5$ & $\mathrm{I}+5$ & $\mathrm{I}+5$ & $\mathrm{I}+5$ & - \\
\hline Gilrakers & 12 & - & - & - & - & - \\
\hline Linea lateralis scal & 56 & - & - & - & - & - \\
\hline Operculum rays & VII & - & - & - & - & - \\
\hline \multicolumn{7}{|l|}{ Weight (g) } \\
\hline Total weight & 1254.6 & 1450 & 950 & 1206 & 1377 & - \\
\hline Gonad & $+2.2-\widehat{\jmath} 4.82$ & 7.5 & 6.8 & - & $+1.2-\bigcirc^{\top} 0.7$ & - \\
\hline Otolith measurements $(\mathrm{mm})$ & Right / Left & & & & & \\
\hline Width & $9.21 / 8.99$ & - & - & - & - & - \\
\hline Height & $5.067 / 5.223$ & - & - & - & - & - \\
\hline Weight (g) & $0.0463 / 0.0455$ & - & - & - & - & - \\
\hline
\end{tabular}

Otolith length, width, and weight measured as $9.21 \mathrm{~mm}, 5.07 \mathrm{~mm}$, and $0.0463 \mathrm{~g}$, respectively. There were no statistical differences in morphological measurements for both right and left otoliths. 
Only single growth ring was determined both right and left sagittal otoliths and age were identified as 1 (Figure 2).

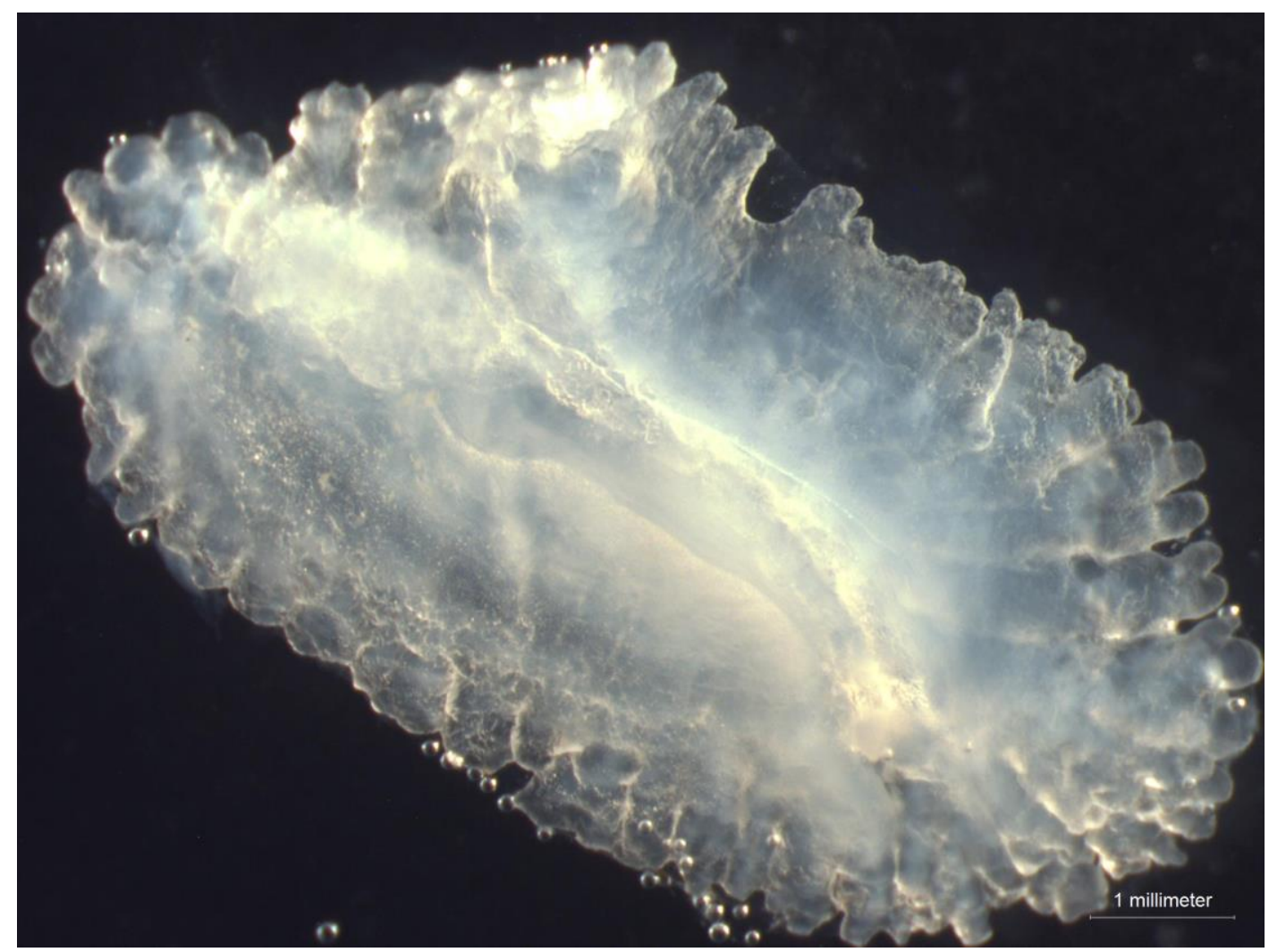

Figure 2. Right sagittal otolith of L. surinamensis

According to macroscopic observation, sex was determined as a hermaphrodite. Female gonad was observed as small, dully transparent, and pinkish-whitish, and sexual maturity defined as 2nd stage. Also, testis was whitish to creamy and determined as 3rd stage (Figure 3a). The stomach was weighted as $12.56 \mathrm{~g}$ and only a single prey type was observed. Preys were poorly digested, so species of fish in the stomach content identified as Atherina boyeri (Figure 3b).
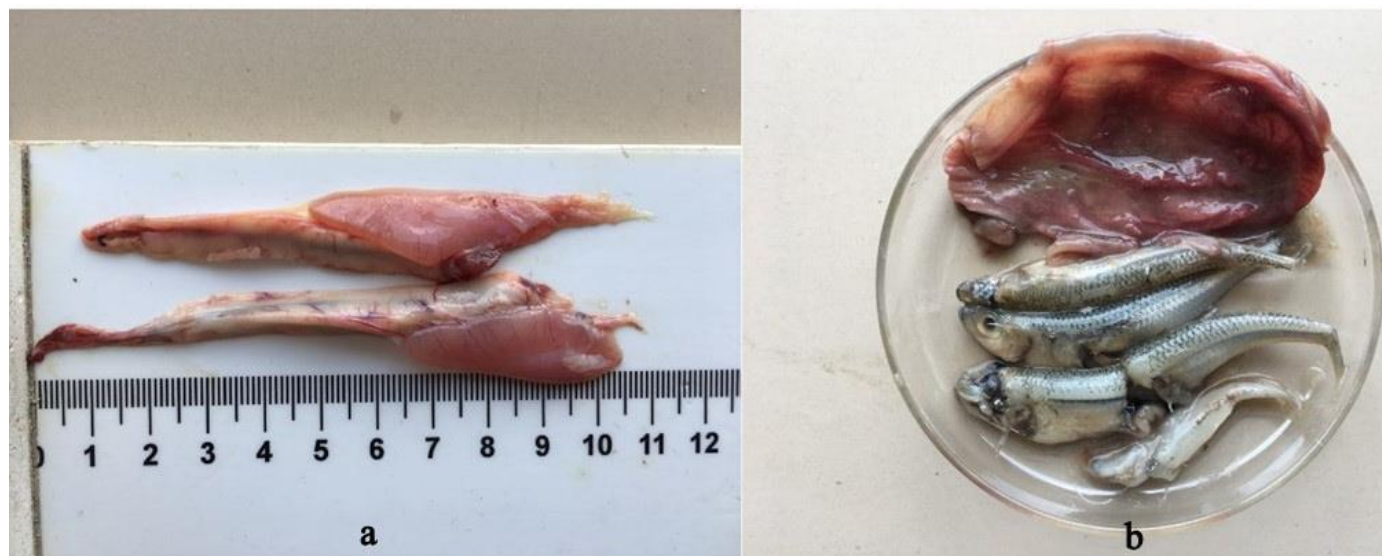

Figure 3. a) Hermaphrodite gonad of L. Surinamensis b) stomach content and prey type (A. boyeri)

\section{DISCUSSION}

Azzurro (2008) described Atlantic Tripletail as a native Mediterranean species whose range is expanding northwards. On the contrary, lots of researchers identified this species as a thermophilic non-native fish species. Tiralongo et al. (2018) were detected a well-established population around the Southern Tyrrhenian Sea, in the Central Mediterranean. In recent years, some juvenile specimens has been recorded from varied regions in the Mediterranean (Deidun et al., 2010; Tiralongo et al., 2018; 
Ergüden et al., 2018). According to these results, it seems that Atlantic Tripletail can be defined as a native species of the Mediterranean.

The northernmost distribution of Atlantic Tripletail in the Mediterranean has been given in some works. Atlantic Tripletail has been reported from Barcelona shores in Western Mediterranean (Palom, 1991); from Rasa Bay, Adriatic (Dulcic et al., 2014b); from Izmir Bay, Central Aegean Sea (Akyol and Kara, 2012) and Dardanelles, North Aegean Sea (Tuncer and Onal, 2016). Minasidis et al. (2020) were lastly recorded around the Northwesternmost shores of the Aegean Sea (Strimonikos Gulf, Delta Evrou, Thermaikos Gulf, and the Thracian Sea). They were reported 5 individuals in the area between 2018 and 2019. In this study, the single hermaphrodite specimen was caught with gillnets on 12 June 2018 around Sultaniçe shores, Saros Bay, North Aegean Sea. This record constituted the Northernmost occurrence of the Atlantic Tripletail in the Turkish part of the Aegean Sea. Minasidis et al. (2020) were collected their records as part of the citizen science project. Authors stated that Atlantic Tripletail has become more common in the region. This hypothesis was supported by this simultaneous report. Atlantic Tripletail may become more common and reproduction may occur soon. Therefore, the early life stages and juveniles of the species should be closely monitored.

Morphometric measurements and meristic counts were given and compared in Table 1. Our findings on morphometric measurements were consistent with the findings of Kechaou et al. (2018) and De Carlo et al. (2017). However, some differences were observed on the morphometric measurement of $39 \mathrm{~cm}$ TL individual of Amor et al. (2016). These differences mostly occurred in head length, prepelvic length, and predorsal length. As can be seen in Figure 1, these measurements were relatively higher for $39 \mathrm{~cm}$ TL individuals. When compared the morphometric data with the findings of the study conducted in the Sea of Oman (Javad et al., 2015), relatively the same values were obtained by percentage of the total length. Information on population dynamics and reproductive biology is absent due to the lack of extensive stock in the Mediterranean. The knowledge on the biology of Atlantic Tripletail has been revealed around Mexico Gulf. Strelcheck et al. (2004) were evaluated 119 specimens, ranging in size from 293 to $763 \mathrm{~mm}$ TL. Sexual maturity of females was estimated as between 494 and $594 \mathrm{~mm}$ TL and approximately approximately 1 and 2 years old. They stated that the diet of Atlantic Tripletail mainly consists of shrimps, pelagic fish species, and crabs. Authors detected that the ratio of fish consumed as prey increased with increasing of the Atlantic Tripletail length. Besides, they argued that consumed fish constituted $\% 31$ of total prey in weight. Franks et al. (2003) were determined the feeding habits of Atlantic Tripletail around Mississippi, Gulf of Mexico. Authors were found that fishes and Crustaceans constituted total prey abundance, equally. In our study, we observed that a single hermaphrodite specimen could not reach the first maturity with its $379 \mathrm{~mm}$ TL according to Strelcheck's (2004) results. Synchronous hermaphroditism was determined in the studies conducted in the Ligurian Sea (De Carlo et al., 2017) and North Aegean Sea (Minos and Economidis, 2007). In both these studies, no ripe female gonads were observed. Since none of these studies had histological gonad evaluation, information about reproductive biology is insufficient.

Only a single growth ring was found, so age was determined as 1 . In stomach content, a single prey type was found as small pelagic fish, A. boyeri. Undoubtedly, a single specimen will not give sufficient information in terms of comparison with previous studies. However, age-length key and first sexual maturity length showed close data. As stated by Strelcheck et al. (2004) and Franks et al. (2003), pelagic fish was also found as prey, in this study.

Atlantic Tripletail, L.surinamensis appears to expand it's spread up to the Northernmost of the Aegean Sea. It has not been reported from the Sea of Marmara and the Black Sea, yet. Besides, fewer reports have been found around the Eastern part of the North Aegean Sea, where under the influence of the Black Sea Water (BSW) inflow. BSW, which shows features of lower temperature and salinity, may create a barrier to the spread of the species via the Sea of Marmara and the Black Sea. With the global warming of the waters, we will see whether it can overcome this barrier in the forthcoming years. Beside Minos and Economidis (2007) presented a different hypothesis on the dispersal of this species. According to the authors, seasonal movements of surface currents have influenced on the dispersal of Tripletail due to its co-existence behavior with the floating-mediated passive objects. With the effect of these currents, it expands its distribution to the North in the summer months for foraging and dispersing to new areas. Although it is difficult to present an opinion on this issue with a single individual, the sampling time of individual (June) may confirm this hypothesis. 
Consequently, the spread of uncommon species in a region should be monitored in terms of ecological balance. The knowledge on stock structure, reproductive capability, and feeding ecology should be increased. Potential impacts on their new habitat should be identified.

\section{ACKNOWLEDGEMENT}

We would like to thanks to local fishermen for sharing samples and opinions.

\section{REFERENCES}

Akyol, O., \& Kara, A. (2012). Record of the Atlantic tripletail, Lobotes surinamensis (Bloch, 1790) in the bay of Izmir, northern Aegean Sea. Journal of Applied Ichthyology, 28, 645-646.

Al-Jufaili, M.S., Hermosa, G., Al-Shuaily, S.S., \& Al Mujaini, A. (2010). Oman Fish Biodiversity. Journal of King Abdulaziz University, Marine Science, 21(1), 3-51.

Amor, B.O.K., Amor, B.M.M., Souissi, B.J., \& Capapè, C. (2016). Unusual records of Tripletail Lobotes surinamensis (Osteichthyes: LOBOTIDAE) from the Tunis Southern Lagoon (North-Eastern Tunisia, Central Mediterranean Sea). Annales Series Historia naturalis, 26(1), 13-18.

Azzurro, E. (2008). The advance of thermophilic fishes in the Mediterranean sea: overview and methodological questions. Climate warming and related changes in Mediterranean marine biota. CIESM Workshop Monographs, Monaco. Helgoland, 27-31 May 2008.

Brown-Peterson, N., \& Franks, J.S. (2001). Aspects of the reproductive biology of tripletail, Lobotes surinamensis, in the northern Gulf of Mexico. Proceedings of the Gulf and Caribbean Fisheries Institute, 52, 586-597.

Bilge, G., Filiz, H., \& Gülşahin, A. (2017). Occurrence of Lobotes surinamensis (Osteichthyes: Lobotidae) in the Mediterranean: Historical and recent data. Zoology in the Middle East, 63(1), 43-47.

Camilleri, M., Ragonese, S., Darmanin, M., \& Rosso, B. (2005). The discovery of a specimen of Lobotes surinamensis off the Maltese islands (Central Mediterranean Sea). Biologia Marina Mediterranea, 12, 480-483.

De Carlo, F., Massaro, A., Musumeci, C., Rossetti, I., Sartor, P., \& Ligas, A. (2017). A new record of Atlantic tripletail, Lobotes surinamensis (Bloch, 1790), in the Ligurian Sea (NW Mediterranean). Journal of Applied Ichthyology, 33, 539-541.

Deidun, A., Sammut, R., Sciberras, A., \& Vella, P. (2010). On the increasing occurrence of Lobotes surinensis in Maltese coastal waters. Aquatic Invasions, 5(1), 113-116.

Doderlein, P. (1875). Descrizione di una species del genere esotico Lobotes preso nell acque dei Contorno Palermo. Atti della Accademia di Scienze: Palermo 5, 1-12. (in Italian).

Dulčić, J., Dragičević, B., Lipej, L., \& Štifanić, M. (2014a). Range extension of tripletail Lobotes surinamensis (Lobotidae) in the Adriatic Sea. A northernmost record in the Mediterranean. Cybium, 38, 153-154.

Dulčić, J., Dragičević, B., Antolović, N., Sulić-Šprem, J., Kozul, V., \& Grgičević, R. (2014b). Additional records of Lobotes surinamensis, Caranx crysos, Enchelycore anatina, and Lagocephalus sceleratus (Actinopterygii) in the Adriatic Sea. Acta Ichthyologica et Piscatoria, 44, 71-74.

Economidis, P.S. (1973). Cataloque de Poisons de la Grèce. Hellenic Oceanology and Limnology, 11, 421-598.

Ergüden, D., Çekiç, M., Alagöz Ergüden, S., Bayhan, Y.K., \& Altun, A. (2018). Juvenile records on the tripletail, Lobotes surinamensis (Bloch, 1790) from Iskenderun Bay (Northeastern Mediterranean Sea, Turkey). Acta Biologica Turcica, 31(2), 42-45.

Franks, J.S., VanderKooy, K.E., \& Garber, N.M. (2003). Diet of Tripletail, Lobotes surinamensis, from Mississippi Coastal Waters. Gulf and Caribbean Research, 15(1), 27-32.

Froese, R., \& Pauly, D (eds) (2018). FishBase. World Wide Web electronic publication. http://www.fishbase.org, version $(06 / 2018)$.

Gilhen, J., \& McAllister, D.E. (1985). The tripletail, Lobotes surinamensis, new to the fish fauna of the Atlantic coast of Nova Scotia and Canada. The Canadian Field-Naturalist, 99, 116-118.

Golani, D. (1996). The marine ichthyofauna of the eastern Levant. History, inventory and characterization. Israel Journal of Zoology, 42, 15-55.

Gönülal O., \& Güreşen S.O. (2014). A list of macrofauna on the continental shelf of Gökçeada Island (northern Aegean Sea) with a new record (Gryphus vitreus Born, 1778) (Brachiopoda, Rhynchonellata) for the Turkish seas. Journal of Black Sea/Mediterranean Environment, 20, 228-252.

Holden, M.J., \& Raitt, D.F.S. (1974). Manual of Fisheries Science. Part 2-Methods of resource investigation and their application. FAO Fisheries Technical Reports.

Iglesias, S., \& Dery, L. (1981). Age and Growth Studies of Hake (Merluccius merluccius L.) from ICES Divisions VIIIc and IXa. ICES CM 1981/G. Technical Report 38.

Jawad, L., Al-Abri, N., Al-Busaidi, H., \& Al-Mamry, J. M. (2015). Confirmation of the presence of the Atlantic tripletail, Lobotes surinamensis (Bloch, 1790), in the Sea of Oman. Journal of Applied Ichthyology, 31(4), 747- 748. https://doi.org/10.1111/jai.12779. 
Kechaou, S.E., Nouira, R.S., \& Capapè, C. (2018). Additional record of Tripletail Lobotes surinamensis (Osteichthyes: LOBOTIDAE) in Tunisian Waters (Central Mediterranean Sea). Annales, Series Historia Naturalis Archives, 28, 2018,1.

Kharin, V.E., Vyshkvartsev, D.I., \& Maznikova, O.A. (2009). About thentaxonomic status of rare fish species Surinam tripletail Lobotes surinamensis (Lobotidae) and new discovery of this species in Russian waters. Journal of Ichthyology, 49, 32-38.

Manilo, G.L., \& Bogorodsky, V.S. (2003). Taxonomic composition, diversity and distribution of coastal fishes of the Arabian Sea. Journal of Ichthyology, 43(1), 75-149.

Minasidis, V., Doumpas, N., Kleitou, P., Naasan, R., Spryridopoulou, A. Papadamakis, P., \& Giovos I. (2020). Additional Records of Tripletail Lobotes surinamensis (Bloch, 1790), from the Eastern Mediterranean. Thalassas: An International Journal of Marine Sciences, 36, 557-563. https://doi.org/10.1007/s41208020-00244-6.

Minos, G., \& Economidis, P.S. (2007). On the occurrence of tripletait, Lobotes surinamensis (Bloch, 1790) (Pisces: Lobotidae), in North Aegean Sea (Greece). p. 242. In: 12th European congress of ichthyologists. Cavat (Dubrovnik), Croatia, 9-13 September 2007.

Palom, O. (1991). Primera cita de Lobotes surinamensis (Bloch, 1790) (Pisces, Lobotidae) para la ictiofauna iberica. Miscellania Zoologica, 15, 240-242. (in Italian).

Strelcheck, A.J., Jackson, J.B. Cowan Jr. J.H., \& Shipp, R.L. (2004). Age, growth, diet, and reproductive biology of the Tripletail, Lobotes surinamensis, from the North-Central Gulf of Mexico. Gulf of Mexico Science, 22(1), 45-53. https://doi.org/10.18785/goms.2201.04.

Tiralongo, F., Coco, S., Lombardo, B.M., \& Messina, G. (2018). On the presence of a well-established population of Lobotes surinamensis (Bloch, 1790) in the Central Mediterranean Sea. Annales Series Historia naturalis, 28(1), 31-36.

Tortonese, E. (1975). Osteichthyes, Pesci Ossei, Vol.II. In: Fauna d'Italia, Vol. XI. E. Caldirini (Ed.). Calderini, Bologna. (in Italian).

Tunçer, S., \& Önal, U. (2016). The occurrence of theAtlantic tripletail, Lobotes surinamensis (Bloch, 1790), in the Çanakkale Strait. Mediterranean Marine Science, 17(1), 247-248.

Zava, B., Gianguzza, P., \& Riggio, S. (2007). New capture of the tripletail Lobotes surinamensis (Bloch, 1790) in the southern Tyrrhenian Sea (Osteichthyes: Lobotidae) (in Italian with English abstract). Biologia Marina Mediterranean, 14, 370. 